\title{
Effects of PMSG and the prostaglandin F-2 $\alpha$ analogue, cloprostenol, on superovulation, fertilization and egg transport in the ewe
}

\author{
D. Whyman and R. W. Moore \\ Whatawhata Hill Country Research Station, Ministry of Agriculture and Fisheries, \\ Private Bag, Hamilton, New Zealand
}

\begin{abstract}
Summary. Romney ewes were artificially inseminated at the oestrus after treatment with PMSG on Day 12 of the cycle, Cloprostenol on Day 14, or both. PMSG resulted in increased numbers of ovulations and large follicles but Cloprostenol had no effect alone or with PMSG. PMSG and Cloprostenol alone led to reduced proportions of eggs fertilized, and PMSG also reduced the proportion of ewes with fertilized eggs. The distribution of eggs in the reproductive tract indicated more rapid egg transport in ewes treated with PMSG. A greater proportion of eggs was recovered from the uterus in ewes in which oestrus was first detected at night. Cloprostenol, as administered to PMSG-treated ewes in this trial, offered no advantage for the preparation of donor ewes for egg transfer.
\end{abstract}

\section{Introduction}

Pregnant mares' serum gonadotrophin (PMSG) is used extensively to induce superovulation in sheep and other species. The potential and limitations of this technique have been reviewed by Polge \& Rowson (1973) with respect to the preparation of donor ewes for egg transfer. Problems in its use include a wide variation in the ovulatory response, the persistence of large unovulated follicles which can disrupt ovarian cycles, and fertilization failure which commonly accompanies high ovulation rates.

Cloprostenol, an analogue of prostaglandin (PG) F-2 $\alpha$ which is the ovine luteolysin (McCracken et al., 1972), has been used to synchronize oestrus in sheep (Baird \& Scaramuzzi, 1975; Trounson, Willadsen \& Moor, 1976; Tervit, Allison, Smith, Harvey \& Havik, 1976) and fertile eggs have been obtained after treatment with PMSG and Cloprostenol (Trounson et al., 1976; Tervit et al., 1976). In this study we examined whether the use of Cloprostenol would improve the reliability of ovulation rate, egg transport and fertilization.

\section{Materials and Methods}

The experiment was carried out during the breeding season (March-May), using 78 mature Romney ewes which were grazed with 2 vasectomized rams equipped with Sire-Sine harnesses and crayons. The ewes were allocated at random to 4 treatment groups, arranged according to a $2 \times 2$ factorial design. Ewes in Groups 1 and 2 were injected intramuscularly with 1500 i.u. PMSG (Paines \& Byrne Ltd) on Day 12 of the oestrous cycle (oestrus = Day 0) and, 2 days later, ewes in Groups 1 and 3 were given an intramuscular injection of $100 \mu \mathrm{g}$ Cloprostenol 
(I.C.I. 80 996). The ewes were checked daily for crayon marks at $06: 00$ and 18:00 h, and were inseminated artificially at the first oestrus after treatment. The insemination dose was $5 \times 10^{8}$ spermatozoa which were collected from Romney rams by the use of an artificial vagina, and the inseminations were carried out within $12 \mathrm{~h}$ after the onset of oestrus and $12 \mathrm{~h}$ later. Fresh, undiluted semen of average concentration $3.2 \times 10^{9}$ spermatozoa $/ \mathrm{ml}$ and average motility $7 \cdot 1$ (on a scale of 1 to 8 ) was used.

The ewes were killed 72-96 $\mathrm{h}$ after the onset of oestrus: the ovaries were weighed and the numbers of corpora lutea $(\mathrm{CL})$ and follicles $\geq 2 \mathrm{~mm}$ diameter were recorded. Follicles with a diameter of $\geq 6 \mathrm{~mm}$ were sectioned and examined for the presence of luteinized tissue. The oviducts and cervix were separated from each uterus, which was then weighed. The oviducts were divided at the ampullary-isthmus junction and eggs were recovered by flushing the lumen of each ampulla and isthmus with $10 \mathrm{ml}$ saline $(9 \mathrm{~g} \mathrm{NaCl} / 1)$. The uterine horns were separated from the body of the uterus and flushed with $30 \mathrm{ml}$ saline. The stage of cleavage of the eggs was determined and those eggs which had undergone cleavage were assumed to have been fertilized.

Statistical analyses were by the methods of Snedecor (1956). Analysis of variance was applied to the data on oestrous cycle lengths and uterine weights, but this was not suitable for certain comparisons of ovarian weights, CL counts, follicular response and number of fertilized eggs per ewe in view of the large differences in variation. In these cases Student's $t$ tests, allowing for unequal variances, were used to assess treatment effects. Homogeneity of variances was estimated by Bartlett's test. Egg recovery rates, fertilization rates, and the distribution of eggs among regions of the reproductive tract, were analysed by $\chi^{2}$ tests.

\section{Results}

Oestrous cycles ranged in length from 14 to 18 days, but there were no significant treatment effects on cycle length. Values in PMSG-treated ewes (Groups 1 and 2) were higher than those in Groups 3 and 4 for uterine weight, ovarian weight, number of $C L$ and total follicular response (Table 1). The uterine weight was lower in Group 3 than in Group 4 ewes.

Table 1. Effect of PMSG and Cloprostenol on oestrous cycle length, uterine and ovarian weights, number of ovulations, total follicular response, and recovery of fertilized eggs (mean \pm s.ẹ.m.)

\begin{tabular}{|c|c|c|c|c|c|c|c|}
\hline Group & $\begin{array}{l}\text { No. of } \\
\text { ewes }\end{array}$ & $\begin{array}{l}\text { Oestrous } \\
\text { cycle } \\
\text { (days) }\end{array}$ & $\begin{array}{l}\text { Uterine wt } \\
\quad(\mathrm{g})\end{array}$ & $\begin{array}{l}\text { Ovarian wt } \\
\text { (g) }\end{array}$ & $\begin{array}{l}\text { No. of } \\
\text { CL }\end{array}$ & $\begin{array}{c}\text { Total } \\
\text { follicular } \\
\text { response }\end{array}$ & $\begin{array}{l}\text { No. of } \\
\text { fertilized } \\
\text { eggs/ewe }\end{array}$ \\
\hline 1 & $19 \ddagger$ & $15.9 \pm 0.2$ & $57 \cdot 3 \pm 2 \cdot 1$ & $8 \cdot 6 \pm 2 \cdot 0$ & $7 \cdot 6 \pm 1 \cdot 0$ & $12 \cdot 1 \pm 0.6$ & $1.9 \pm 0.6$ \\
\hline 2 & 19 & $15 \cdot 9 \pm 0.2$ & $58.8 \pm 2.9$ & $5 \cdot 9 \pm 2 \cdot 0$ & $7 \cdot 0 \pm 1 \cdot 1$ & $10.5 \pm 0.6$ & $1.3 \pm 0.5$ \\
\hline 3 & 19 & $16 \cdot 3 \pm 0 \cdot 2$ & $46 \cdot 7 \pm 1 \cdot 5$ & $2 \cdot 2 \pm 0 \cdot 1$ & $1 \cdot 3 \pm 0 \cdot 1$ & $1.8 \pm 0.2$ & $0.4 \pm 0.1$ \\
\hline 4 & 21 & $16 \cdot 2 \pm 0 \cdot 2$ & $52.0 \pm 1.9$ & $2 \cdot 3 \pm 0 \cdot 1$ & $1 \cdot 6 \pm 0 \cdot 1$ & $1.9 \pm 0.1$ & $1.0 \pm 0.2$ \\
\hline \multicolumn{8}{|c|}{ Difference due to: } \\
\hline \multicolumn{2}{|c|}{ PMSG $(1+2)-(3+4)$} & $-0.4 \pm 0.2$ & $\begin{array}{l}8 \cdot 7 \\
\pm 2 \cdot 2^{* * *}\end{array}$ & $\begin{aligned} & 5 \cdot 0 \\
\pm & 1 \cdot 2^{* *}\end{aligned}$ & $\begin{aligned} & 5.8 \\
\pm & 0.7^{* * *}\end{aligned}$ & $\begin{aligned} & 9.4 \\
\pm & 1.4^{* * * *}\end{aligned}$ & $0.9 \pm 0.4$ \\
\hline \multicolumn{2}{|c|}{$\begin{array}{l}\text { Cloprostenol } \\
\qquad(1+3)-(2+4)\end{array}$} & $0.1 \pm 0.2$ & - & 一 & - & 一 & - \\
\hline \multicolumn{2}{|c|}{ Cloprostenol + PMSG $1-2$} & - & $\begin{array}{r}-1.5 \\
\pm 3.6\end{array}$ & $\begin{array}{r}2.7 \\
\pm 2.4\end{array}$ & $\begin{array}{r}0.6 \\
\pm 1.5\end{array}$ & $\begin{array}{r}1.6 \\
\pm 2.7\end{array}$ & $0.6 \pm 0.8$ \\
\hline \multicolumn{2}{|c|}{$\begin{array}{l}\text { Cloprostenol, no PMSG } \\
3-4\end{array}$} & - & $\begin{array}{l}-5 \cdot 3 \\
\pm 2 \cdot 5^{*}\end{array}$ & $\begin{array}{l}-0.1 \\
\pm 0.1\end{array}$ & $\begin{array}{l}-0.3 \\
\pm 0.2\end{array}$ & $\begin{array}{l}-0.1 \\
\pm 0.2\end{array}$ & $-0.6 \pm 0.2$ \\
\hline
\end{tabular}

$\uparrow$ Number of $\mathrm{CL}+$ number of follicles $\geq 6 \mathrm{~mm}$ diameter.

$\ddagger$ One ewe did not ovulate.

${ }^{*} P<0.05$; $^{* *} P<0.01$; $^{* *} P<0.001$. Main effects obtained by factorial analysis of variance; effect of Cloprostenol assessed by Student's $t$ tests in cases where PMSG caused a large increase in variation. 
Twenty-two of the ewes in Groups 3 and 4 had one CL and the remainder (18) had two. There was a marked increase in the number of CL per ewe in response to PMSG; 87\% of ewes in Groups 1 and 2 had more than two CL with a range of $0-18 \mathrm{CL}$ per ewe. The ovulation rate was unaffected by Cloprostenol, both with respect to the mean number of CL and the variability of the ovulatory response, whether or not the ewes had previously received PMSG. The total follicular response showed less variability $(P<0.05)$ in PMSG-treated ewes (Groups 1 and 2 ) than did the number of $\mathrm{CL}$ alone.

Table 2. Effect of PMSG and Cloprostenol on the incidence of ewes with at least one follicle of different sizes, and on the number of follicles per ewe

\begin{tabular}{|c|c|c|c|c|c|c|c|c|c|}
\hline \multirow[b]{3}{*}{ Group } & \multirow{3}{*}{$\begin{array}{l}\text { No. of } \\
\text { ewes }\end{array}$} & \multicolumn{4}{|c|}{ No. (\%) of ewes with follicles of: } & \multicolumn{4}{|c|}{ Mean (and max.) number of follicles/ewe } \\
\hline & & \multicolumn{4}{|c|}{ Follicular diameter $(\mathrm{mm})$} & \multicolumn{4}{|c|}{ Follicular diameter (mm) } \\
\hline & & $2-5$ & $6-9$ & $10-13$ & $\geq 14$ & $2-5$ & $6-9$ & $10-13$ & $\geq 14$ \\
\hline 1 & 19 & $15(78.9)$ & $3(15 \cdot 8)$ & $3(15 \cdot 8)$ & $8(42 \cdot 1)$ & $5.4(15)$ & $0.7(3)$ & $1.8(7)$ & $2.0(14)$ \\
\hline 2 & 19 & $17(89 \cdot 5)$ & $7(36 \cdot 8)$ & $3(15 \cdot 8)$ & $4(21 \cdot 1)$ & $7 \cdot 3(17)$ & $1.8(14)$ & $1 \cdot 2(13)$ & $0.5(7)$ \\
\hline 3 & 19 & $19(100)$ & $5(26 \cdot 3)$ & $1(5 \cdot 3)$ & 0 & $6 \cdot 8(13)$ & $0.5(2)$ & $0.1(1)$ & 0 \\
\hline 4 & 21 & $21(100)$ & $6(28 \cdot 6)$ & $1(4 \cdot 8)$ & 0 & $8.4(22)$ & $0.3(1)$ & $0 \cdot 1(1)$ & 0 \\
\hline
\end{tabular}

All ewes had at least one follicle $\geq 2 \mathrm{~mm}$ diameter, and when all follicles measuring $\geq 2 \mathrm{~mm}$ were considered, Student's $t$ tests showed no significant treatment effects on the mean numbers of follicles (Table 2). The numbers of follicles $\geq 6 \mathrm{~mm}$ diameter and the numbers of ewes with such follicles were increased $(P<0.001)$ in Groups 1 and 2 but were not affected in Group 3 . Values in Groups 1 and 2 were similar. In 2 of the ewes in Group 2 and 4 in Group 1 partial luteinization had occurred in up to 4 follicles $\geq 6 \mathrm{~mm}$ diameter. The remaining follicles examined were not luteinized.

Table 3. Egg recovery and fertilization rates

\begin{tabular}{|c|c|c|c|c|c|c|}
\hline \multirow[b]{2}{*}{ Group } & \multirow[b]{2}{*}{$\begin{array}{l}\text { No. of } \\
\text { ewes }\end{array}$} & \multicolumn{2}{|c|}{ No. (\%) of ewes } & \multirow[b]{2}{*}{$\begin{array}{l}\text { No. of } \\
\text { CL }\end{array}$} & \multicolumn{2}{|c|}{ No. (\%) of eggs } \\
\hline & & Yielding eggs & $\begin{array}{l}\text { Yielding fertilized } \\
\text { eggs* }\end{array}$ & & Recovered & Fertilized $\dagger$ \\
\hline 1 & 19 & $18(94 \cdot 7)^{\mathrm{Aa}}$ & $9(50 \cdot 0)^{A \mathrm{Aa}}$ & 144 & $84(58 \cdot 3)^{\wedge a}$ & $36(42.9)^{\mathrm{Aa}}$ \\
\hline 2 & 19 & $18(94.7)^{\mathrm{Aa}}$ & $6(33 \cdot 3)^{B b}$ & 132 & $79(59.9)^{\mathrm{Aa}}$ & $24(30.4)^{A a}$ \\
\hline 3 & 19 & $13(68.4)^{\mathrm{Ab}}$ & $7(53 \cdot 8)^{\mathrm{Aa}}$ & 25 & $18(72 \cdot 0)^{\mathrm{Bb}}$ & $8(44.4)^{\mathrm{ABa}}$ \\
\hline 4 & 21 & $18(85 \cdot 7)^{\mathrm{Aab}}$ & $14(77 \cdot 8)^{\mathrm{Az}}$ & 33 & $26(78 \cdot 8)^{\mathrm{Bb}}$ & $20(76 \cdot 9)^{\mathrm{Bb}}$ \\
\hline \multicolumn{7}{|c|}{ Significance of main effects: } \\
\hline \multirow{2}{*}{\multicolumn{2}{|c|}{$\begin{array}{l}\text { PMSG }(1+2)-(3+4) \\
\text { Cloprostenol }\end{array}$}} & $P<0.05$ & $P<0.05$ & & $P<0.001$ & n.s. \\
\hline & & n.s. & n.s. & & n.s. & n.s. \\
\hline
\end{tabular}

* Ewes yielding at least one fertilized egg, expressed as a percentage of all ewes yielding eggs.

$\dagger$ Expressed as a percentage of eggs recovered.

Values within columns with different superscripts are significantly different by $\chi^{2}$ test $(A B, P<0.01 ; a, b$, $P<0.05$ ).

Table 3 summarizes egg recovery and fertilization rates. Complete recovery of eggs from the reproductive tract, assuming one egg to have originated from each $\mathrm{CL}$, was achieved in 38 ewes, and at least 1 egg was recovered from 67 of the 77 ewes which had ovulated. An empty zona pellucida was flushed from each of 4 tracts; in 2 of these intact eggs were also recovered and it is probable that the empty zonae resulted from mechanical damage during the recovery process. There was a reduction in the percentage of eggs recovered in Groups 1 and 2. The success of egg recovery was, however, probably related to the number of eggs available rather than the 
treatment because at least one egg was recovered from $94.7 \%$ of ewes in Groups $1+2$ compared with $77.5 \%$ in Groups $3+4(P<0.05)$, although egg recovery was complete for only 30.6 and $87.1 \%$ respectively $(P<0.001)$.

Fertilization rate was affected in Groups 1, 2 and 3. The measure of success in fertilizing ewes was obtained from the number of ewes from which at least one fertilized egg was recovered as a percentage of the total number of ewes yielding eggs. This value was reduced in Group 2. There were no significant treatment effects on the mean number of fertilized eggs obtained per ewe (Table 1).

The positions of the eggs recovered from the reproductive tracts are shown in Table 4. Eggs in Groups 1 and 2 were more frequently found in the uterus. The number of eggs recovered per ewe was not related to their position in the reproductive tract.

Table 4. Numbers (and \%) of eggs recovered from different regions of the reproductive tract of treated ewes

\begin{tabular}{ccrr}
\hline & \multicolumn{3}{c}{ Region from which eggs recovered } \\
\cline { 2 - 4 } Group & Ampulla & Isthmus & Uterus \\
\hline 1 & $24(29)$ & $29(35)$ & $31(37)^{\mathrm{a}}$ \\
2 & $31(39)$ & $14(18)$ & $34(43)^{\mathrm{a}}$ \\
3 & $11(61)$ & $5(28)$ & $2(11)^{\mathrm{b}}$ \\
4 & $17(65)$ & $6(23)$ & $3(12)^{\mathrm{b}}$ \\
Fertilized eggs & $41(47)$ & $25(28)$ & $22(25)$ \\
Unfertilized eggs & $42(35)$ & $29(24)$ & $48(40)$ \\
\hline
\end{tabular}

Values with different superscripts are significantly different $(P<0.05)$ by $\chi^{2}$ test. The main effect of PMSG (Groups $\left.1+2\right)-$ (Groups $3+4$ ) on numbers of eggs in the uterus is significant at $P<0.001$.

The distributions of fertilized and unfertilized eggs in different regions of the reproductive tract did not differ significantly. Fertilized and unfertilized eggs were recovered from 11 ewes: in 8 all the eggs were flushed from the same section of the reproductive tract. The development of the fertilized eggs ranged from 2 to 16 blastomeres, and eggs in all stages were recovered from the oviducts and the uterus.

The data give evidence of a diurnal effect related to the time of the start of oestrus. Eggs were flushed from the reproductive tracts at 72-84 $\mathrm{h}$ after the start of oestrus in ewes recorded as marked at $06: 00 \mathrm{~h}$, and at 84-96 h in those recorded at 18:00 h. There was no significant difference in fertilization rate related to the time of onset of oestrus, but the proportion of eggs found in the uterine horns of ewes detected in oestrus at $06: 00 \mathrm{~h}(58.0 \%)$ was greater $(P<$ $0.001)$ than that of ewes detected in oestrus at 18:00 $\mathrm{h}(21.7 \%)$.

\section{Discussion}

The ovarian response to PMSG was characterized by increased ovarian weight, multiple ovulations and the occurrence of cystic follicles, with a high degree of variability in each of these responses, as is regularly obtained with this treatment (Polge \& Rowson, 1973). The less variable total follicular response in PMSG-treated ewes supports the hypothesis that some of the stimulated follicles are unable to respond to the ovulatory stimulus. The administration of Cloprostenol in an attempt to control the timing of luteal regression and hence of oestrus and the ovulatory stimulus did not reduce the variation in ovulation rate or in the incidence of large $(\geq 6$ $\mathrm{mm}$ diameter) follicles. Cloprostenol was injected at a time when cytological regression and 
perhaps also functional regression of the $\mathrm{CL}$ would have begun in many of the ewes (Deane, Hay, Moor, Rowson \& Short, 1966; Bjersing, Hay, Moor, Short \& Deane, 1970). Since, however, a single injection of Cloprostenol at the dosage used in this experiment is sufficient to induce luteolysis followed by ovulation when administered at mid-cycle (Trounson et al., 1976), this treatment was expected to have an overriding influence on luteal regression irrespective of the secretion of endogenous prostaglandin F-2a. The use of a superovulation regimen involving the administration of Cloprostenol at mid-cycle has been reported (Tervit et al., 1976) to result in premature regression of $\mathrm{CL}$ with consequent poor egg recovery, which these authors suggested may be associated with an hormonal effect on egg transport. There was no evidence of premature luteal regression in the present experiment, but PMSG did have a detrimental effect on egg recovery.

Egg recovery was timed to coincide with the expected passage of eggs from the oviducts into the uterine horns, assuming that ovulation occurs approximately $24 \mathrm{~h}$ after the onset of oestrus (Whyman, Johnson, Knight \& Moore, 1979) and that eggs enter the uterus about $60 \mathrm{~h}$ after ovulation (Holst \& Braden, 1972; Holst, 1974). The times of ovulations in relation to oestrus and to each other generally show limited variation in PMSG-treated and untreated ewes (Whyman et al., 1979). However, Cognié, Mariana \& Thimonier (1970) and Boshoff, van Niekerk \& Morgenthal (1973) showed that PMSG can advance the time of ovulation in relation to the onset of oestrus by as much as $15 \mathrm{~h}$. This could be a contributory factor influencing the greater proportion of eggs that reached the uterus in PMSG-treated ewes, but in view of the length of time that elapsed between oestrus and egg recovery ( $84 \mathrm{~h}$ on average), it is probable that the distribution of eggs within the reproductive tract was largely a reflection of the rate of egg transport through the tract. PMSG increased the rate of egg transport and reduced the proportions of eggs fertilized. Robinson (1951) suggested that these two effects may be inter-related in PMSG-treated ewes, but the primary response has not been identified. A simulatory effect of PMSG on the reproductive tract was indicated by the increase in uterine weight due to this hormone. This probably resulted indirectly from increased ovarian steroid secretion, although correlations between uterine weight and various measures of follicle growth were not significant. Cloprostenol alone also reduced fertilization rate, but without reducing the uterine weight and without affecting the rate of egg transport.

The diurnal influence of the time of oestrus in relation to egg transport is difficult to explain. The interval between oestrus and egg collection was $12 \mathrm{~h}$ shorter on average in ewes starting oestrus at night, yet more eggs were found in the uterus in these ewes. A difference in the mean oestrus-to-ovulation interval of more than $12 \mathrm{~h}$ would be necessary to account for the distribution of eggs on the basis of the timing of ovulation alone. Alternatively, there may have been a diurnal influence at mating resulting in modification of the secretion rate of pituitary hormone over the following 4 days with a consequent effect on the rate of egg transport.

Cloprostenol, as administered to PMSG-treated ewes in this trial, offered no advantage for the preparation of donor ewes for egg transfer.

We thank Mr K. E. Jury for statistical analysis, and Mrs S. H. Rowe, Mr K. G. Ferris, Mr P. R. Lynch and Mr P. H. Evans for technical assistance. Cloprostenol was supplied by I.C.I. (N.Z.) Ltd.

\section{References}

Baird, D.T. \& Scaramuzzi, R.J. (1975) Prostaglandin F- $2 \alpha$ and luteal regression in the ewe: comparison with 16 Aryloxyprostaglandin (I.C.I. 80,966). Annls Biol. anim. Biochim. Biophys. 15, 161-174.

Bjersing, L., Hay, M.F., Moor, R.M., Short, R.V. \& Deane, H.W. (1970) Endocrine activity, histochemistry and ultrastructure of ovine corpora lutea. 1.
Further observations on regression at the end of the oestrous cycle. Z. Zellforsch. mikrosk. Anat. 111, 437-457.

Boshoff, D.A., van Niekerk, C.H. \& Morgenthal, J.C. (1973) Time of ovulation in the Karakul ewe following synchronization of oestrus. S. Afr. J. Anim.

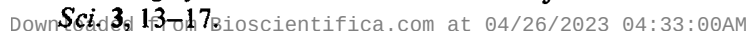


Cognié, Y., Mariana, J.C. \& Thimonier, J. (1970) Etude du .moment d'ovulation chez la brebis normale ou traitée par un progestagène associé ou non à une injection de PMSG. Annls Biol. anim. Biochim. Biophys. 10, 15-24.

Deane, H.M., Hay, M.F., Moor, R.M., Rowson, L.E.A. \& Short, R.V. (1966) The corpus luteum of the sheep: relationships between morphology and function during the oestrous cycle. Acta endocr. Copenh. 51, 245-263.

Holst, PJ. (1974) The time of entry of ova into the uterus of the ewe. J. Reprod. Fert. 36, 427-428.

Holst, P.J. \& Braden, A.W.H. (1972) Ovum transport in the ewe. Aust. J. biol. Sci. 25, 167-173.

McCracken, J.A., Carison, J.C., Glew, M.E., Goding, J.R., Baird, D.T., Gréen, K. \& Samueisson, B. (1972) Prostaglandin F-2 $\alpha$ identified as a luteolytic hormone in sheep. Nature, New Biol. 238, 129-134.

Polge, C. \& Rowson, L.E.A. (1973) Recent progress in techniques for increasing reproductive potential in farm animals. Proc. 3rd Wld Conf. Anim. Prod. Vol. 3, 633-643.

Robinson, TJ. (1951) The control of fertility in sheep. Part II. The augmentation of fertility by gonadotrophin treatment of the ewe in the normal breeding season. J. agric. Sci., Camb. 41, 6-63.

Snedecor, G.W. (1956) Statistical Methods, 5th edn. Iowa State College Press.

Tervit, H.R., Allison, A.J., Smith, J.F., Harvey, T.M. \& Havik, P.G. (1976) Egg transfers in exotic sheep. Proc. N.Z. Soc. Anim. Prod. 36, 67-75.

Trounson, A.O., Willadsen, S.M. \& Moor, R.M. (1976) Effect of a prostaglandin analogue Cloprostenol on oestrus, ovulation and embryonic viability in sheep. J. agric. Sci., Camb. 86, 609-611.

Whyman, D., Johnson, D.L., Knight, T.W. \& Moore, R.W. (1979) Intervals between multiple ovulations in PMSG-treated and untreated ewes and the relationship between ovulation and oestrus. J. Reprod. Fert. $55,481-488$.

Received 17 September 1979 